\title{
Effect of Acute Lung Injury on VLA-4 and CXCR4 Expression in Resident and Circulating Hematopoietic Stem/Progenitor Cells
}

\author{
Teresa Trotta $^{a}$ Sante Di Gioia ${ }^{b}$ Donatella Piro ${ }^{b}$ Silvia Lepore ${ }^{d}$ \\ Santina Cantatore ${ }^{a}$ Chiara Porro $^{a}$ Stefano Castellani ${ }^{b}$ Antonio Petrella $^{c}$ \\ Francesca Fortunato $^{b}$ Angela B. Maffione $^{a}$ Massimo Conese $^{b}$ \\ Departments of a Clinical and Experimental Sciences and ${ }^{b}$ Medical and Surgical Sciences, University of Foggia, \\ and ${ }^{\mathrm{C} I s t i t u t o}$ Zooprofilattico di Puglia e Basilicata, Foggia, and d Department of Oncohematology, IRCCS, Referral \\ Cancer Center of Basilicata, Rionero in Vulture, Italy
}

\section{Key Words}

Acute lung injury $\cdot$ Chemotaxis $\cdot$ Hematopoietic

stem/progenitor cells $\cdot$ Integrins $\cdot$ L-selectin

\begin{abstract}
Background: The effect of acute lung injury on adhesion molecule expression in hematopoietic stem/progenitor cells (HSPCs) is poorly understood. Objectives: The aim of this study was to determine whether there is a relationship between pulmonary inflammation, expression of VLA-4 (CD49d), LFA-1 (CD11a), L-selectin (CD62L), CXCR4, and chemotaxis in resident HSPCs, as well as the level of circulating HSPCs. Methods: Following intratracheal administration of a single LPS bolus in C57BI/6 mice, the number of inflammatory cells, differential counts, and amounts of cytokines/ chemokines were studied in cytospins and bronchoalveolar lavage fluid (BALF) specimens. Expressions of adhesion molecules and CXCR4 were analyzed in HSPCs by flow cytometry, as well as SDF-1-directed chemotaxis. Levels of HSPCs in the blood were studied in ungated and circulating subpopulations. Results: In coincidence with a peak of airway neutrophils, cytokine (IL-1 $\beta$, TNF- $\alpha$, and IL-6), chemokine (KC, MIP-2, and SDF-1) levels in BALF and the number of
\end{abstract}

marrow HSPCs expressing CD49d and CXCR4 significantly increased at $48 \mathrm{~h}$. The number of CD49d- and CXCR4-positive HSPCs dropped at $72 \mathrm{~h}$. The HSPC subset comprising bigger cells behaved the same for CD49d. Chemotaxis of the marrow HSPC subset of bigger cells was higher in LPS-treated animals than in controls at 72 h. Finally, we could detect a significant decrease in circulating Sca- $1^{+}$cells in the mononuclear population at $72 \mathrm{~h}$ in LPS-treated mice. Conclusions: Our data provide evidence for a temporal relationship between pulmonary inflammation, CD49d and CXCR4 expression fluctuation in resident HSPCs, and the level of circulating HSPCs.

Copyright $\odot 2012$ S. Karger AG, Basel

\section{Introduction}

Acute lung injury (ALI) and its most severe manifestation, acute respiratory distress syndrome, is a clinical syndrome whose pathological features are: increased endothelial and epithelial permeability, alveolar edema, elevat-

\section{T.T. and S.D.G. contributed equally to this work.}

\section{KARGER}

Fax +4161306 1234

E-Mail karger@karger.ch

www.karger.com (c) 2012 S. Karger AG, Basel

$0025-7931 / 13 / 0853-0252 \$ 38.00 / 0$

Accessible online at:

www.karger.com/res
Prof. Massimo Conese

Department of Medical and Surgical Sciences

University of Foggia, c/o Ospedali Riuniti

Viale L. Pinto 1, IT-71122 Foggia (Italy)

Tel. +390881 588 019, E-Mail m.conese@unifg.it 
ed increase in cytokine concentrations in the lung, and neutrophilic alveolar infiltrates [1]. One of the best models reproducing the human disease is the administration of lipopolysaccharide (LPS) in the mouse lung $[2,3]$. In the airways, inflammatory stimuli, such as a microbes or LPS, induce a rapid and massive release of neutrophils from the bone marrow [4]. Later, monocytes, lymphocytes, and platelets are also released. The pulmonary recruitment of these cells is important for host defense and resolution of an inflammatory response. Moreover, inflammatory stimuli, such as LPS, a component of Gram-negative bacterial cell walls, in the lung airways induce a rapid mobilization of bone marrow-derived endothelial progenitor cells (EPCs) into the circulation of mice. EPCs then accumulate within the inflammatory site and differentiate to become endothelial and epithelial cells [5]. Human studies have also indicated that EPCs are important and required for lung repair after bacteria-induced lung injury [6]. Although the critical role of hematopoietic stem/progenitor cells (HSPCs) in initiating LPS-induced neutrophil recruitment from the vascular space to the airspace has been documented [7], likely contributing to the macrophage population, the role of adhesion molecules in their egress from the bone marrow is not understood in this model of pulmonary inflammation. The current view regarding the retention of HSPCs within the bone marrow stem cell niche is that it depends mainly on two molecular pathways: the adhesion molecules $\alpha_{4} \beta_{1}$-integrin [very late activation antigen-4 (VLA-4) or CD49d/CD29] and vascular cell adhesion molecule (VCAM)-1, and the CXCR4stromal derived factor-1 (SDF-1 or CXCL12) chemokine pathways $[8,9]$. Disruption of the VLA-4-VCAM-1 and CXCR4-CXCL12 axes by blocking antibodies [10] and functional antagonists [11] and in genetically deficient mice [12-14] has resulted in HSPC mobilization. Additional pathways probably participate in a cooperative or synergistic fashion [reviewed in 15]. The role of the socalled leukocyte integrins that share the common $\beta_{2}$ (CD18) chain, $\alpha_{\mathrm{L}} \beta_{2}$ [lymphocyte function-associated antigen-1 (LFA-1) or CD11a/CD18] and $\alpha_{M} \beta_{2}$ (macrophage-1 antigen, $\mathrm{CD} 11 \mathrm{~b} / \mathrm{CD} 18)$, is still under debate. Although some studies have reported their involvement in HSPC retention $[16,17]$, others have indicated that the effect of $\beta_{2}$-integrins becomes apparent only in synergy with $\alpha_{4} \beta_{1}$ [18]. HSPCs have also been shown to express L-selectin $[19,20]$; however, the role of L-selectin in HSPC mobilization is still controversial [reviewed in 8,21].

We have correlated the expression of adhesion molecules on resident and circulating HSPCs with pulmonary inflammation determined by LPS administration. This study provides evidence of a temporal relationship between pulmonary inflammation, expression of VLA-4 and CXCR4, chemotaxis of resident marrow HSPCs, and the number of HSPCs in the blood.

\section{Materials and Methods}

\section{Model of ALI}

All animal procedures were approved and controlled by the Institutional Review Board of the University of Foggia/Istituto Zooprofilattico of Puglia and Basilicata and by the Italian Ministry of Health and carried out according to the guidelines of the Italian law on protection of animal life and the Helsinki Declaration. The experiments were performed using 6- to 8-week old male C57Bl/6 mice (Charles River Laboratories, Calco, Italy) with a body weight of 23-27 g. They were housed and handled according to institutional guidelines which comply with Italian legislation and were given food and water ad libitum.

ALI was induced by intratracheal administration of LPS from Pseudomonas aeruginosa (serotype 10; Sigma). Mice were anesthetized intraperitoneally with 2,2,2-tribromoethanol (Avertin, prepared $2.5 \%$ weight/volume in PBS and used $0.015 \mathrm{ml} / \mathrm{g}$ body weight; Sigma) and restrained in a vertical position with their necks tilted back so as to result in an accessible position of the trachea for intubation. Using two pairs of tweezers, the mouth was carefully opened and the tongue was gently pulled out. Then, each animal received a single $50-\mu$ l bolus of LPS in saline $(20 \mu \mathrm{g})$ or $50 \mu \mathrm{l}$ of saline (control mice) introduced into the trachea using a 22-gauge intravascular cannula sleeve with the needle removed ( $25 \mathrm{~mm}, 0.9 \mathrm{~mm}$ OD, $0.6 \mathrm{~mm}$ ID; Baxter, Germany). To avoid false intubation into the esophagus, the trachea was illuminated via an otoscope held perpendicularly to the animal's throat, producing a well-illuminated trachea through dispersed light.

To obtain bronchoalveolar lavage fluid (BALF) specimens, the trachea was exposed through a midline incision and cannulated with a sterile 23 -gauge needle. BAL was performed by instilling $0.9 \% \mathrm{NaCl}$ in two separate $1-\mathrm{ml}$ aliquots. The fluid was recovered by gentle suction and placed on ice for immediate processing. An aliquot of the BALF was processed immediately for total and differential cell counts. Total cell counts were performed with a hemocytometer, whereas differential cell counts were performed on cytospin preparations stained with the May-Grunwald Giemsa stain. The remainder of the lavage fluid was spun at $200 \mathrm{~g}$ for 10 min, and supernatant was removed aseptically and stored in individual aliquots at $-80^{\circ} \mathrm{C}$.

After lavage, lungs were removed and fixed in formaldehyde. The fixed samples were embedded in paraffin, thin-sectioned, and mounted on glass microscope slides using standard histopathological techniques. Serum was obtained from blood drawn by cardiac puncture of anesthetized mice.

The amounts of cytokines and chemokines were determined in BALF supernatants using commercially available multiplex sandwich ELISA according to the protocol provided by the manufacturer (Searchlight Mouse Chemochine/Cytokine Array; Thermo Fisher Scientific, Waltham, Mass., USA). SDF-1 was measured in serum samples by commercial ELISA (Cusabio Biotech, Wuhan, PR China). 


\section{Bone Marrow Cell Isolation}

Both ends of the femur and tibia of the sacrificed mice, as described above, were removed and the bone marrow was flushed out with PBS using a needle. Recovered total bone marrow cells were filtered (Cell trics 100 mm; Partec, Münster, Germany), centrifuged, washed, and resuspended in PBS supplemented with $2 \%$ FBS and $1 \mathrm{~mm}$ EDTA. The total number of cells was determined with a Burker cytometer. Positive selection of bone marrow stem/ progenitor cells by EasySep (Mouse Scal selection kit; StemCell Technologies) was done accordingly to the manufacturer's instructions. Briefly, recovered total bone marrow cells, resuspended in the appropriate medium, were incubated with the anti-Sca-1; PE-conjugated antibody was added to isolated bone marrow cells. Then, tetrameric antibody complex, which recognizes both PE and dextran, was added, followed by the addition of dextran-coated magnetic nanoparticles. Magnetically labeled target cells were then separated from unlabeled unwanted cells using the EasySep magnet by pouring the unlabeled cells off.

\section{Immunostaining and Cytofluorimetric Analysis of Sca- $1^{+}$}

HSPCS

For each time point, 3-4 mice in the saline- and LPS-treated experimental groups were used to obtain a pool of HSPCs. Aliquots of $2 \times 10^{5} \mathrm{Sca}-1^{+} \mathrm{HSPCs}$ were pelleted by centrifugation at $337 \mathrm{~g}$ for $10 \mathrm{~min}$ at $+4^{\circ} \mathrm{C}$, resuspended in $100 \mu \mathrm{l}$ of PBS, and then incubated with FITC-conjugated monoclonal antibodies (used at 1:200) for $30 \mathrm{~min}$ at $+4^{\circ} \mathrm{C}$. The monoclonal antibodies tested were: rat IgG2b $\kappa$ anti-mouse CD49d, rat IgG2a $\kappa$ anti-mouse CD11a, rat IgG2a $\kappa$ anti-mouse CD62L, and rat IgG2b $\kappa$ antimouse CXCR4. Isotype control antibodies were also used. All antibodies were purchased from BioLegend (San Diego, Calif., USA), except for anti-CXCR4 antibody which was from eBioscience (San Diego, Calif., USA). After incubation, the cells were pelleted, washed twice with PBS, and analyzed by fluorescence-activated cell sorting (FACS) with an EPICS XL MCL flow cytometer (Beckman Coulter, Fullerton, Calif., USA).

\section{Ki67 Cytofluorimetric Assay}

For each time point, 3-4 mice in the saline- and LPS-treated experimental groups were used to obtain a pool of HSPCs. Sca- $1^{+}$ HSPCs $\left(2 \times 10^{5}\right)$ were fixed in PBS containing $3 \%$ paraformaldehyde and $2 \%$ sucrose for $5 \mathrm{~min}$ at room temperature, permeabilized in PBS containing $20 \mathrm{~mm}$ Hepes, $300 \mathrm{~mm}$ sucrose, $5 \mathrm{~mm}$ $\mathrm{NaCl}, 3 \mathrm{mM} \mathrm{MgCl}_{2}$, and $0.5 \%$ Triton-X100 for $5 \mathrm{~min}$ at room temperature, incubated with rabbit monoclonal anti-Ki67 antibody (FITC-conjugated) (used at 1:100; Abcam, Cambridge, UK) for 30 min at $+4{ }^{\circ} \mathrm{C}$, and then analyzed by flow cytofluorimetry. An isotype control antibody was also used.

\section{Immunostaining and FACS Analysis of Circulating Sca- $1^{+}$ Cells}

For each group per time point, 3-4 mice in the saline- and LPS-treated experimental groups were analyzed. A blood aliquot of $100 \mu \mathrm{l}$, obtained from each mouse, was incubated with rat IgG2a $\kappa$ anti-Sca-1 PE-conjugated antibody (used at 1:100; StemCell Technologies) and either a cocktail of antibodies against $\mathrm{B}$ and T lymphocytes and NK cells (mouse IgG2a $\mathrm{K}$ antimouse NK-1.1, rat IgG2a к anti-mouse CD19, and Armenian hamster IgG anti-mouse $\mathrm{CD} 3 \varepsilon$ ), or rat $\operatorname{IgG} 2 \mathrm{~b} \kappa$ anti-mouse
CD11b for monocytes/macrophages, or rat IgG2b $\kappa$ anti-mouse Ly-6G/Ly-6C (Gr-1) for granulocytes. In parallel, other blood aliquots were incubated with isotype control antibodies. All monoclonal antibodies identifying blood cell populations were FITC-conjugated (BioLegend) and used at 1:200 for $30 \mathrm{~min}$ at $+4^{\circ} \mathrm{C}$. Then, erythrocytes were lysed using the IOTest 3 lysing solution (Immunotech SAS, Beckman Coulter Company, Marseille, France) according to the manufacturer's instructions, and washed and resuspended in PBS for flow cytometer analysis. Dot plots for lineage marker and side scatter were obtained in order to gate lymphocytes, monocytes, and granulocytes. Identified populations were analyzed for Sca-1 expression. The final analysis of double positive cells for Sca-1 and each lineage marker was carried out on ungated lymphomonocytes and granulocytes. The number of granulocytes was obtained by studying the cell population stained with anti-Ly-6G/Ly-6C antibody and with high side scatter.

To identify circulating Sca- $1^{+}$cells expressing adhesion molecules, blood samples were incubated with anti-Sca-1 antibody and either FITC-conjugated anti-mouse CD49d, CD11a or CD62L at a final dilution of 1:200 for $30 \mathrm{~min}$ at $+4^{\circ} \mathrm{C}$. Blood cell populations were identified by forward scatter and side scatter, gated, and used for analysis of double positive cells for Sca-1 and each adhesion molecule.

\section{Transendothelial Chemotaxis Assay}

To induce polarization, bovine aortic endothelial cells (bAEC; Lonza Walkersville, Inc., Walkersville, Md., USA) were seeded into the upper chamber of Transwells with a diameter of $6.5 \mathrm{~mm}$ and pores of $3 \mu \mathrm{m}$ (Costar; Corning Incorporated, USA) and grown for 5 days. Under these conditions, cells grow as a polarized sheet of cells and develop a transendothelial resistance of $50 \Omega \times$ $\mathrm{cm}^{2}$ on average, as measured by a volt ohm meter (Millicell-ERS; Millipore, Vimodrone, Italy).

For each time point, 3-4 mice in the saline- and LPS-treated experimental groups were used to obtain a pool of HSPCs. Sca- $1^{+}$ HSPCs were resuspended in endothelial cell basal medium (EBM; Lonza) and a volume of $300 \mu$ l containing $5 \times 10^{5}$ cells was loaded into the upper chamber of the Transwell. EBM $(600 \mu \mathrm{l})$ with or without recombinant mouse CXCL12/SDF-1 (200 ng/ml; R\&D Systems) was added to the bottom chamber. The assays were performed at $37^{\circ} \mathrm{C}$ for $4 \mathrm{~h}$. Transmigrating cells (bottom chamber) were counted for $120 \mathrm{~s}$ using a flow cytometer.

\section{Statistical Analysis}

Data were evaluated using Prism 4 (GraphPad Software, Inc., La Jolla, Calif., USA). All results are expressed as means \pm SD. The statistical significance of the differences between the mean values of the groups was analyzed by the unpaired test and ANOVA (Tukey's multiple comparison test as post hoc). The Spearman rank test was used for correlation of pulmonary inflammatory parameters with antigen expression by HSPCs, number of circulating cells in blood, and serum SDF-1, and the Spearman correlation coefficient is reported $\left(r_{s}\right)$. Correlation analysis was performed among experimental groups which presented all parameters. $\mathrm{p}<0.05$ was considered statistically significant. 


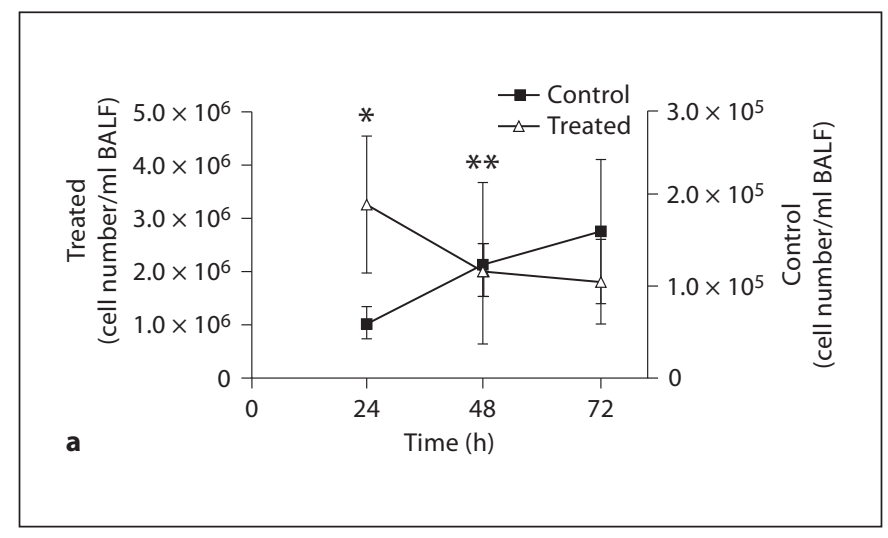

Fig. 1. Inflammatory cells in the BALF of saline-treated mice (controls) and LPS-treated mice. Total (a) and differential (b, c) counts of inflammatory cells were analyzed on cytospins. LPStreated mice showed a higher total number of inflammatory cells than saline-treated mice at $24 \mathrm{~h}(\mathrm{p}<0.05)$ and $48 \mathrm{~h}(\mathrm{p}<0.001)$. Neutrophils made up the prevalent cell type in LPS-treated mice (c) at 48 and $72 \mathrm{~h}$, whereas macrophages were the only cell type found in saline-treated mice at all time points (b). $\mathrm{n}=11-16$ per time point. ${ }^{*} \mathrm{p}<0.05 ;{ }^{* *} \mathrm{p}<0.001$, treated vs. controls.

\section{Results}

\section{LPS Induces a Sustained Pulmonary Inflammation}

In the first part of the study, we sought to characterize the model of pulmonary inflammation obtained by intratracheal instillation of LPS. Histopathologic examination of hematoxylin and eosin-stained lung tissue sections of mice treated with LPS showed massive bronchopneumonia with peribronchial accumulation of inflammatory cells at $24 \mathrm{~h}$ posttreatment. The inflammation persisted at 48 and $72 \mathrm{~h}$. No apparent increase in inflammatory cells was detected in the lungs of salinetreated mice (not shown).

The type and time course changes of the inflammatory cells in BALF after intratracheal instillation with LPS and saline are shown in figure 1 . The total number of inflammatory cells in the BALF of LPS-treated mice was significantly higher than those of saline-treated mice at 24 and $48 \mathrm{~h}$ posttreatment (fig. 1a). The number of inflammatory cells in BALF at $72 \mathrm{~h}$ posttreatment declined in LPS-treated mice. Neutrophils made up the majority of the inflammatory cells in the BALF of LPS-treated
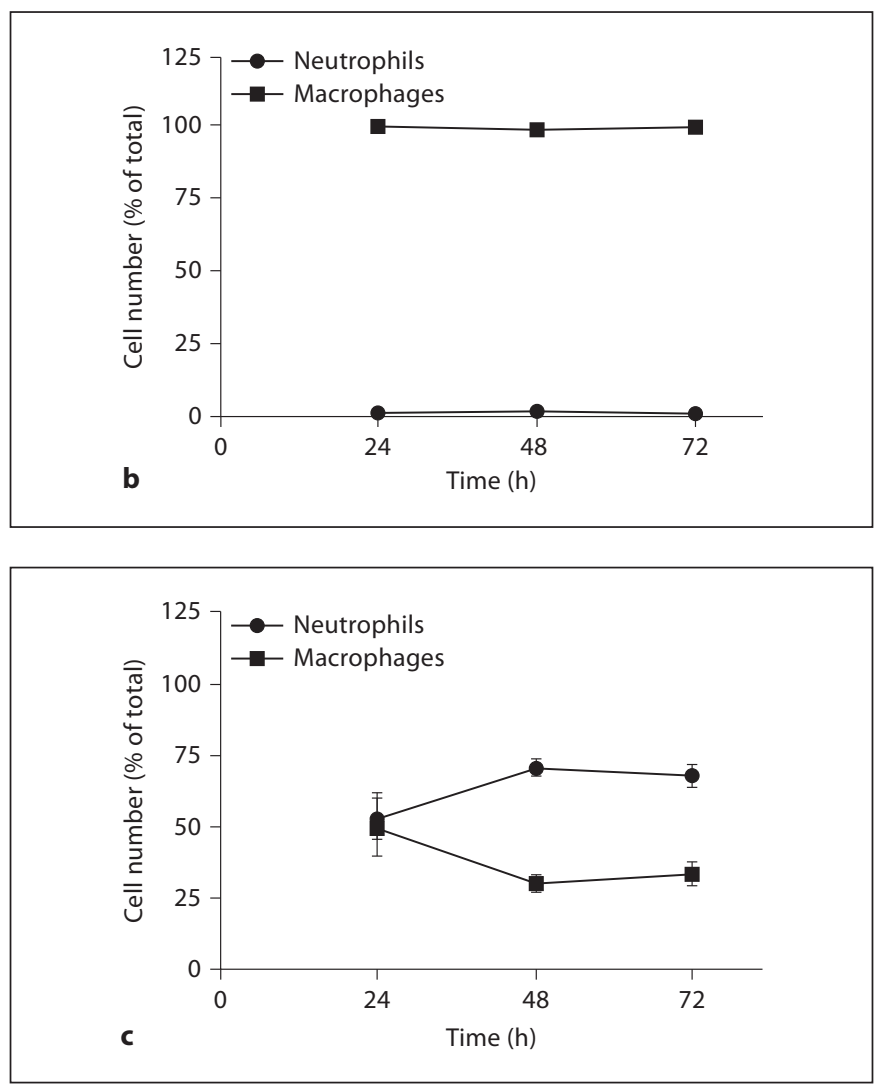

mice at 48 and $72 \mathrm{~h}$ (70\% of total number of cells; fig. 1c), whereas macrophages were the only represented cell type in the saline-treated group (fig. 1b).

A multi-parametric chemiluminescent ELISA was used to study inflammatory cytokines (IL-1 $\beta$, TNF- $\alpha$, and IL-6) and chemokines (KC, MIP-2, and SDF-1) in BALF. IL-1 $\beta$, TNF- $\alpha$, and IL- 6 levels reached a peak at $48 \mathrm{~h}$ in LPS-treated mice (fig. 2a-c). This behavior was also observed for KC and MIP-2, two neutrophil chemokines (fig. 2d, e). Interestingly, SDF-1 levels remained high even at $72 \mathrm{~h}$ (fig. $2 \mathrm{f}$ ).

Altogether, these results showed a sustained inflammatory condition for up to $72 \mathrm{~h}$ in the mouse lung, which was reflected by increased levels of cytokines and chemokines at the same time point.

\section{VLA-4 Expression in HSPCs Fluctuates during Pulmonary Inflammation}

We next determined the effect of sustained pulmonary inflammation on the expression of adhesion molecules in HSPCs isolated from total bone marrow by means of Sca1 positive selection. Cytofluorimetric analysis revealed 
Fig. 2. Cytokine and chemokine levels in BALF. BALF was obtained from LPStreated and saline-treated mice (controls) at 24,48 , and $72 \mathrm{~h}$. Cytokine (IL-1 $\beta$, TNF$\alpha$, and IL-6) and chemokine (KC, MIP-2, and SDF-1) levels were evaluated by a multiplex ELISA. All cytokines and chemokines showed a peak level at $48 \mathrm{~h}$. $\mathrm{n}=$ 4 per time point. ${ }^{*} \mathrm{p}<0.05 ;{ }^{*} \mathrm{p}<0.001$; *** $\mathrm{p}<0.0001$, treated vs. controls.

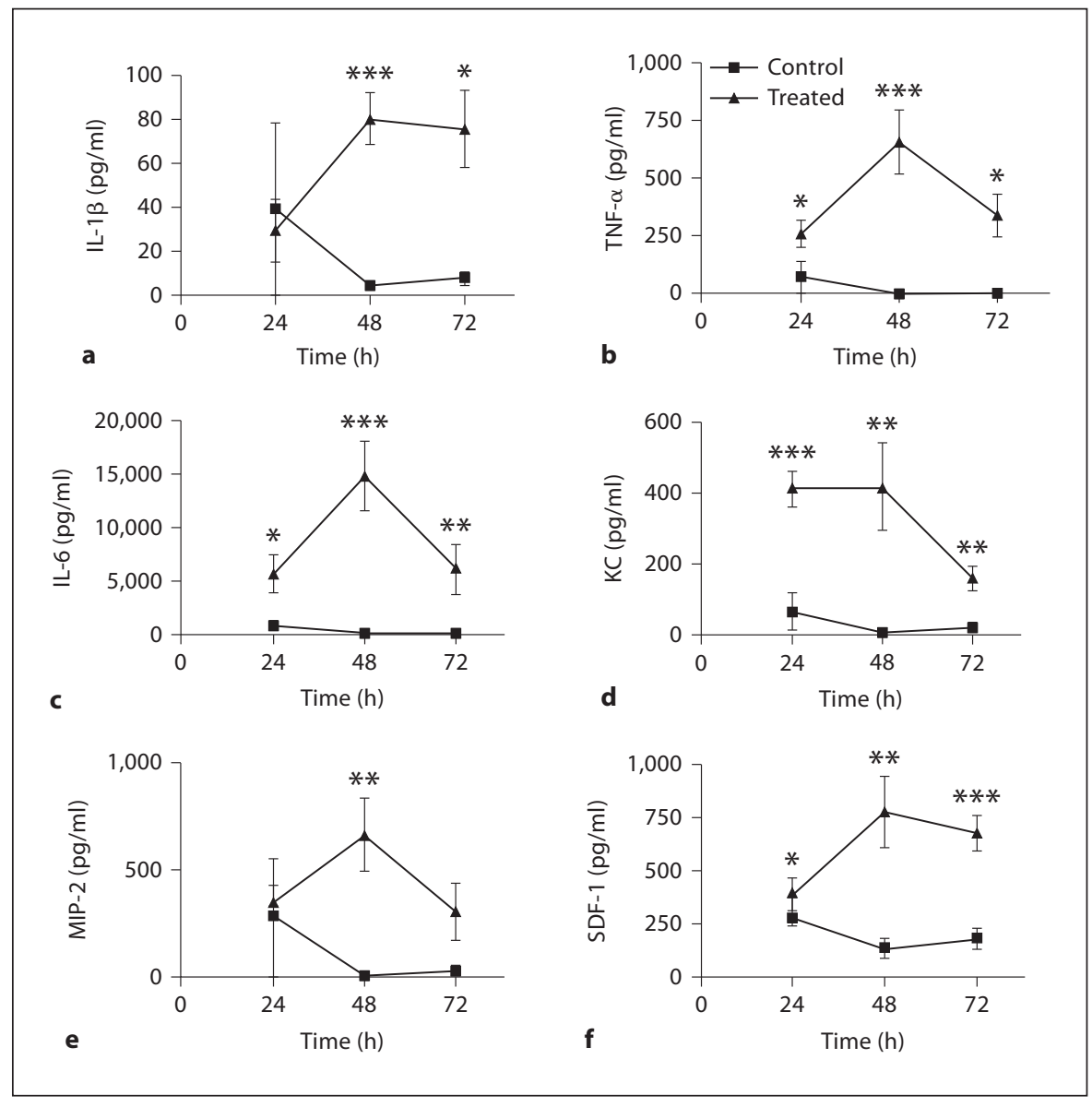

that the number of CD49d (VLA-4), CD11a (LFA-1), and CD62L (L-selectin)-positive cells peaked at $48 \mathrm{~h}$. However, only CD49d-positive cells were significantly higher in LPS-treated mice than in saline-treated mice at $48 \mathrm{~h}$ ( $\mathrm{p}<0.05$; fig. 3a), whereas CD11a- and CD62L-positive cells showed a trend toward increased levels but it was not significant (fig. 3b, c). At $72 \mathrm{~h}$, the number of CD49dpositive cells decreased in LPS-treated mice and was not significant compared to control mice $(\mathrm{p}>0.05)$. Since changes in adhesion receptor expression in HSPCs have been associated with the cell cycle [22], to investigate whether the increase in adhesion molecules is due to the proliferation of HSPCs, we studied Ki67 expression. The expression of this mitogenic marker did not vary among the different time points (fig. 3d). Thus, the inflammatory process in the lung seems to perturb the expression of adhesion molecules in bone marrow HSPCs without affecting mitosis.

We have previously shown that the Sca- $1^{+}$population in naïve mice is comprised of two subpopulations, one smaller and one bigger, according to their physical parameters [23]. These two subsets were further analyzed for CD49d expression in the context of LPS-induced inflammation. The biggest population (R1) was comprised of cells always with a higher expression of CD49d than the smallest population (R2) both in controls and in LPStreated mice (fig. 4). R1 cells showed higher levels of CD49d than R2 cells at $48 \mathrm{~h}$ post-LPS administration $(\mathrm{p}<0.05)$, resembling the behavior of the total marrow population. At $72 \mathrm{~h}$, the percentage of CD49d-positive cells decreased in LPS-treated mice and was not significant compared to control mice ( $p>0.05)$. Although R2 cells also showed an increase at $48 \mathrm{~h}$ post-LPS administration compared to the control mice, this difference was not significant $(\mathrm{p}>0.05)$.

Since CD49d was the adhesion molecule which presented significant fluctuation during the pulmonary inflammatory process, we sought to find any correlation with lung parameters. There was a positive correlation between expression of CD49d by resident HSPCs and 

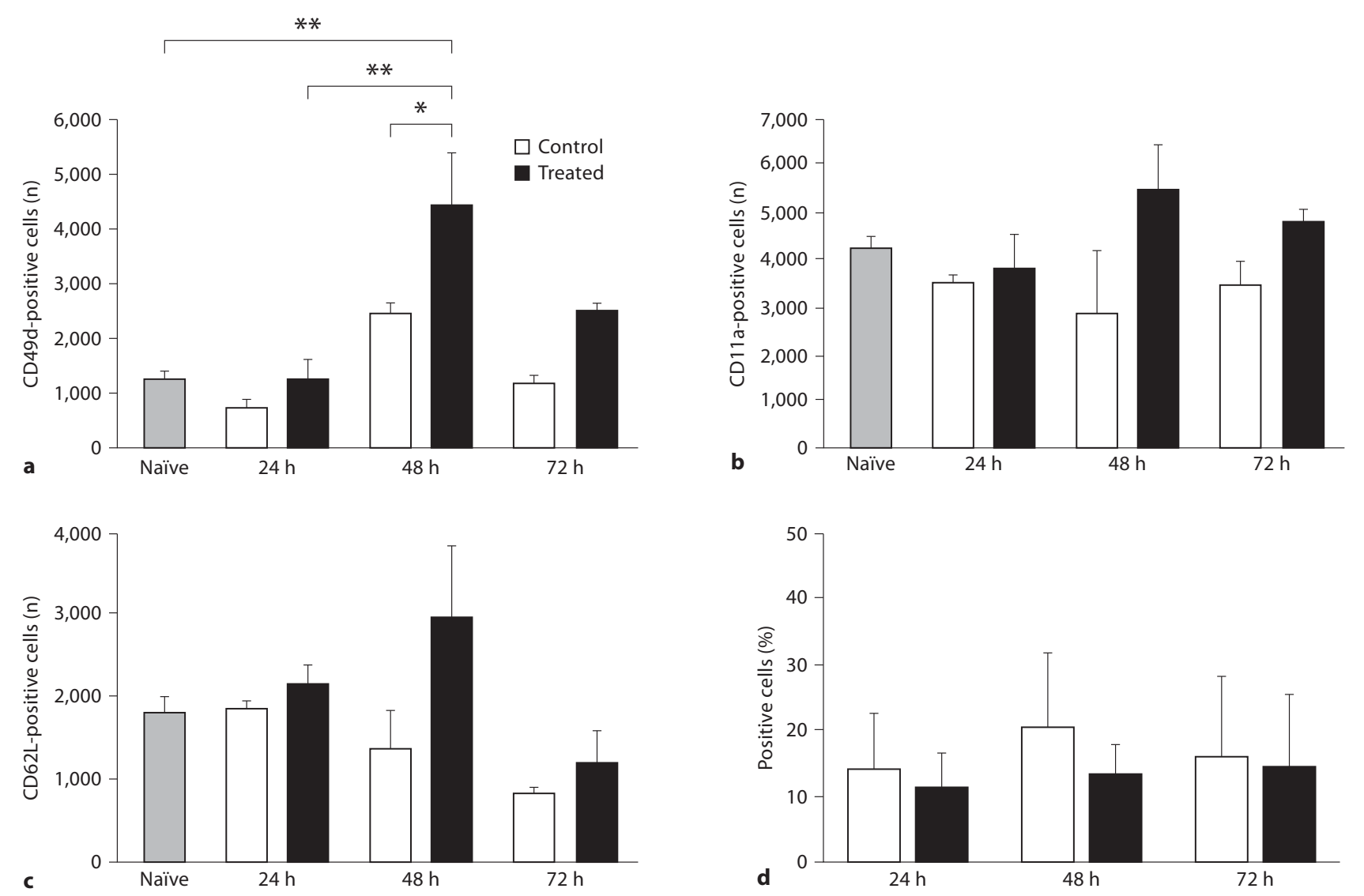

Fig. 3. Expression of adhesion molecules and Ki67 in HSPCs. CD49d (a), CD11a (b), and CD62L (c) expression was studied by cytofluorimetry in naïve mice and in mice treated either with saline (controls) or LPS (treated). Ki67 expression (d) was evaluated in controls and treated mice. Data are expressed as numbers of events $(\mathbf{a}-\mathbf{c})$ or percentages of positive cells $(\mathbf{d})$ and shown as the mean \pm SD of 3 experiments (cell pools from 3-4 mice were used for each time point and each group). ${ }^{*} \mathrm{p}<0.05 ;{ }^{* *} \mathrm{p}<0.001$. some pulmonary cytokine/chemokine levels in BALF: at $48 \mathrm{~h}$ with IL-1 $\beta$ and MIP-2, and at $72 \mathrm{~h}$ with $\mathrm{KC}$ (all $\mathrm{r}_{\mathrm{s}}=$ 1 and $\mathrm{p}<0.001)$. Of note, CD49d expression in the R1 subpopulation of HSPCs correlated with SDF-1 at $48 \mathrm{~h}$ and with $\mathrm{KC}$ at $72 \mathrm{~h}\left(\right.$ all $\mathrm{r}_{\mathrm{s}}=1$ and $\left.\mathrm{p}<0.001\right)$.

\section{CXCR4 Expression in HSPCs and SDF-1 Levels in}

Serum

We next addressed the question of whether the SDF-1 receptor CXCR4 expression was modified by LPS-induced pulmonary inflammation. Figure 5 a shows that in LPS-treated mice the number of CXCR4-positive cells significantly increased at $48 \mathrm{~h}$ compared to control mice. The CXCR4 number of positive cells at $48 \mathrm{~h}$ was also significantly higher than at $24 \mathrm{~h}$ and compared to naïve mice. No correlation was found between CXCR4 expression by HSPCs and lung inflammatory parameters.

To investigate the role of SDF-1 in the fluctuation of CD49d and CXCR4 in resident HSPCs, we next examined the serum levels of SDF-1, the ligand of CXCR4. The serum concentration of SDF-1 was higher in LPS-treated mice at all time points compared to control mice, reflecting BALF data (fig. 5b). SDF-1 in serum correlated positively with BALF SDF-1 at $72 \mathrm{~h}\left(\mathrm{r}_{\mathrm{s}}=1\right.$ and $\left.\mathrm{p}<0.001\right)$.

\section{SDF-1-Directed Chemotaxis of HSPCs}

Previous studies have shown that the disruption of the CXCL12/CXCR4 axis in C57Bl/6 mice determines HSPCs mobilization [24]. To evaluate the function of CXCR4 on HSPCs during the development of LPS-induced pneumo- 




Fig. 4. Expression of CD49d in HSPC subpopulations. HSPC subsets were studied for CD49d levels by cytofluorimetry at the indicated time points after saline (controls) or LPS (treated) intratracheal administration. Whole Sca- $1^{+}$cells were gated according to their forward and side scatter in two subsets: R1 and R2 (a). Anal-



Fig. 5. SDF-1/CXCR4 axis during LPS-induced pulmonary inflammation. a CXCR4 expression was studied by cytofluorimetry in naivve mice and in mice treated either with saline (controls) or LPS (treated). Data are expressed as numbers of events and shown as the mean \pm SD of 3 experiments (cell pools from 3-4 mice were used

nia, chemotaxis versus a CXCL12/SDF-1 gradient was investigated. To mimic the bone marrow vascular niche, Sca- $1^{+}$cells were allowed to migrate through an endothelial monolayer. SDF-1 increased the migration of Sca- $1^{+}$ cells of naïve mice almost twelve-fold, although this dif-

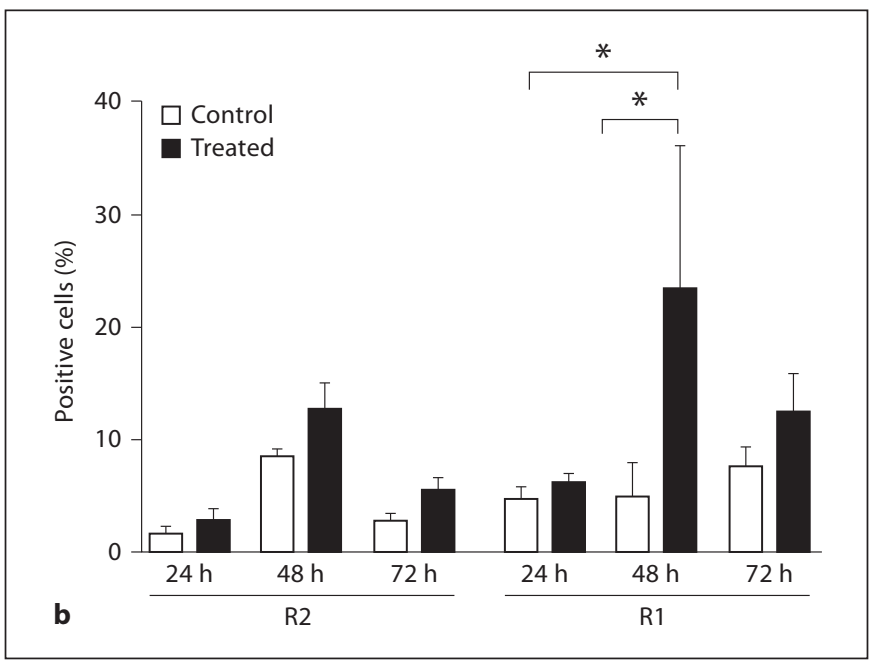

yses of CD49d-positive cells in R1 and R2 gates at different time points and for each experimental group were then performed (b). Data are expressed as percentages of positive cells and shown as the mean \pm SD of 3 experiments (cell pools from 3-4 mice were used for each time point and each group). ${ }^{*} \mathrm{p}<0.05$.

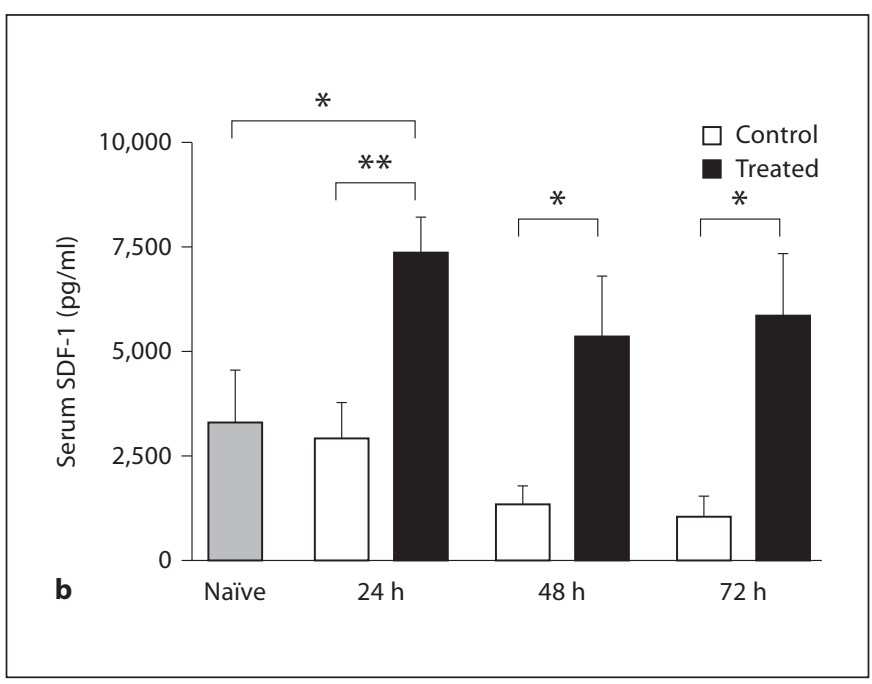

for each time point and each group). ${ }^{*} \mathrm{p}<0.005$. b Serum levels of SDF-1 protein were obtained from naïve mice and mice treated either with saline (controls) or LPS (treated). Data are expressed as picograms per milliliter and shown as the mean \pm SD of 3 experiments ( $\mathrm{n}=6$ mice per each time point). ${ }^{*} \mathrm{p}<0.05 ;{ }^{* *} \mathrm{p}<0.001$.

ference was not statistically significant due to the big SD ( $p>0.05$; fig. 6a). There was a trend toward an increase in cell migration with time in both controls and treated mice; however, SDF-1-induced chemotaxis was significantly higher (6.5-fold) in treated animals compared to 

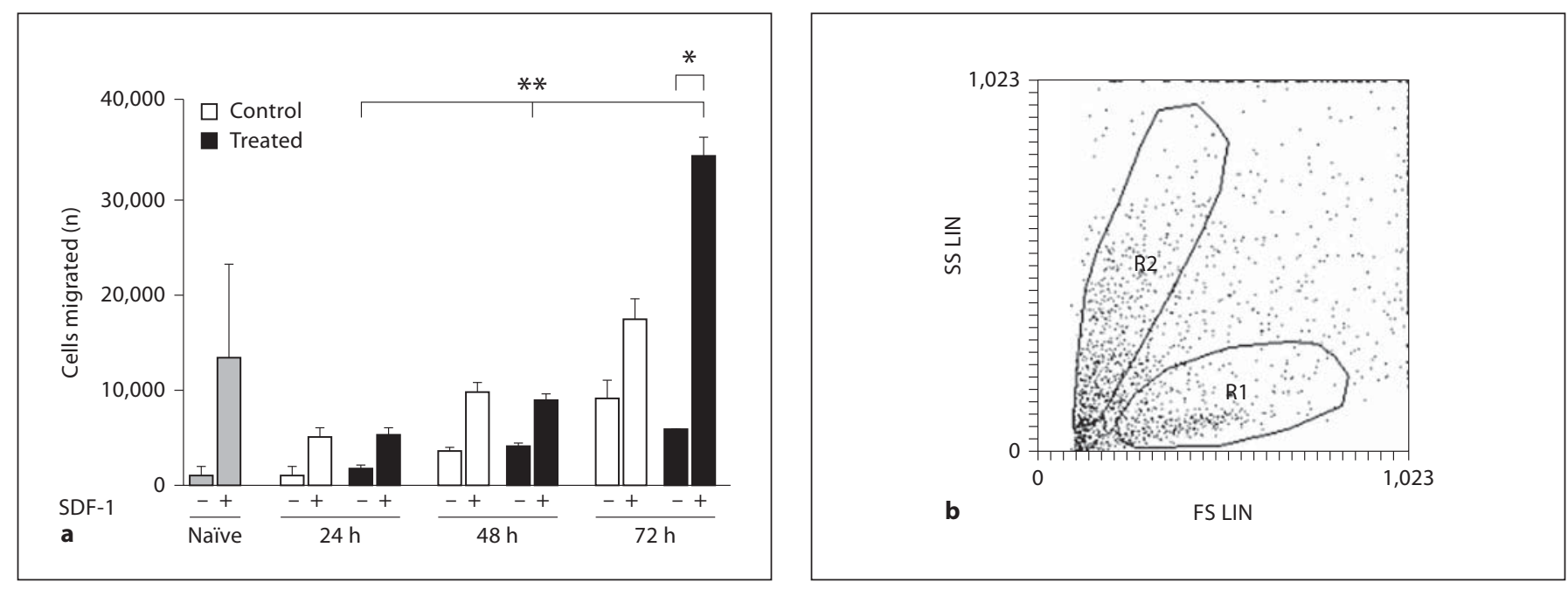

Fig. 6. Effect of LPS administration on chemotaxis of HSPCs. a HSPCs were allowed to migrate through the bAEC monolayer against an SDF-1 gradient for $4 \mathrm{~h}$ and cells that migrated to the bottom of the Transwells were quantified by cytofluorimetry (cell pools from 3-4 mice were used for each time point and each group). Migrated cells were analyzed for R1 and R2 subpopulations in control wells without SDF-1 (b) and in SDF-1-containing wells (c). ${ }^{*} \mathrm{p}<0.05 ;{ }^{* *} \mathrm{p}<0.001$.

controls at $72 \mathrm{~h}(\mathrm{p}<0.05)$. We sought to understand whether the two HSPC subpopulations were differently able to migrate against the SDF-1 gradient. It was the case since only R1 bigger cells were found in the lower well in SDF-1-stimulated chemotaxis (fig. 6c), while this different behavior was not observed in unstimulated HSPCs (fig. 6b).

\section{Levels of Circulating Sca- $1^{+}$HSPCs and Adhesion \\ Molecule Expression}

To study the level of circulating HSPCs during the inflammatory response in the lung, the number of HSPCs, as identified by the expression of the Sca-1 antigen, was studied in the blood. LPS administration determined significant neutrophilia at $48 \mathrm{~h}$ compared to controls, which persisted at $72 \mathrm{~h}$ (fig. 7a). Naïve mice presented $6.6 \pm$

$2.5 \%, 7.0 \pm 3.0 \%$, and $0.4 \pm 0.2 \%$ (mean $\pm \mathrm{SD}$ ) of Sca- $1^{+}$ in the ungated, lymphomonocyte, and granulocyte populations, respectively, showing that almost all circulating HSPCs were in the mononuclear population. We could detect a significant decrease in Sca- $1^{+}$cells in the ungated population and mononuclear cells at $72 \mathrm{~h}$ following LPS administration compared to controls (fig. 7b, c). Although, for unknown reasons, the number of Sca- $1^{+}$cells was high when studied in the ungated and lymphomonocyte populations of control mice at $72 \mathrm{~h}$, this was not statistically significant compared to all of the other time points. Interestingly, the number of Sca- $1^{+}$cells in the granulocyte population significantly increased at $48 \mathrm{~h}$ (fig. $7 \mathrm{~d}$ ), in parallel with the increase in absolute numbers of blood granulocytes. The levels of adhesion molecules were studied on Sca- $1^{+}$cells. Although there was a trend towards a decrease 


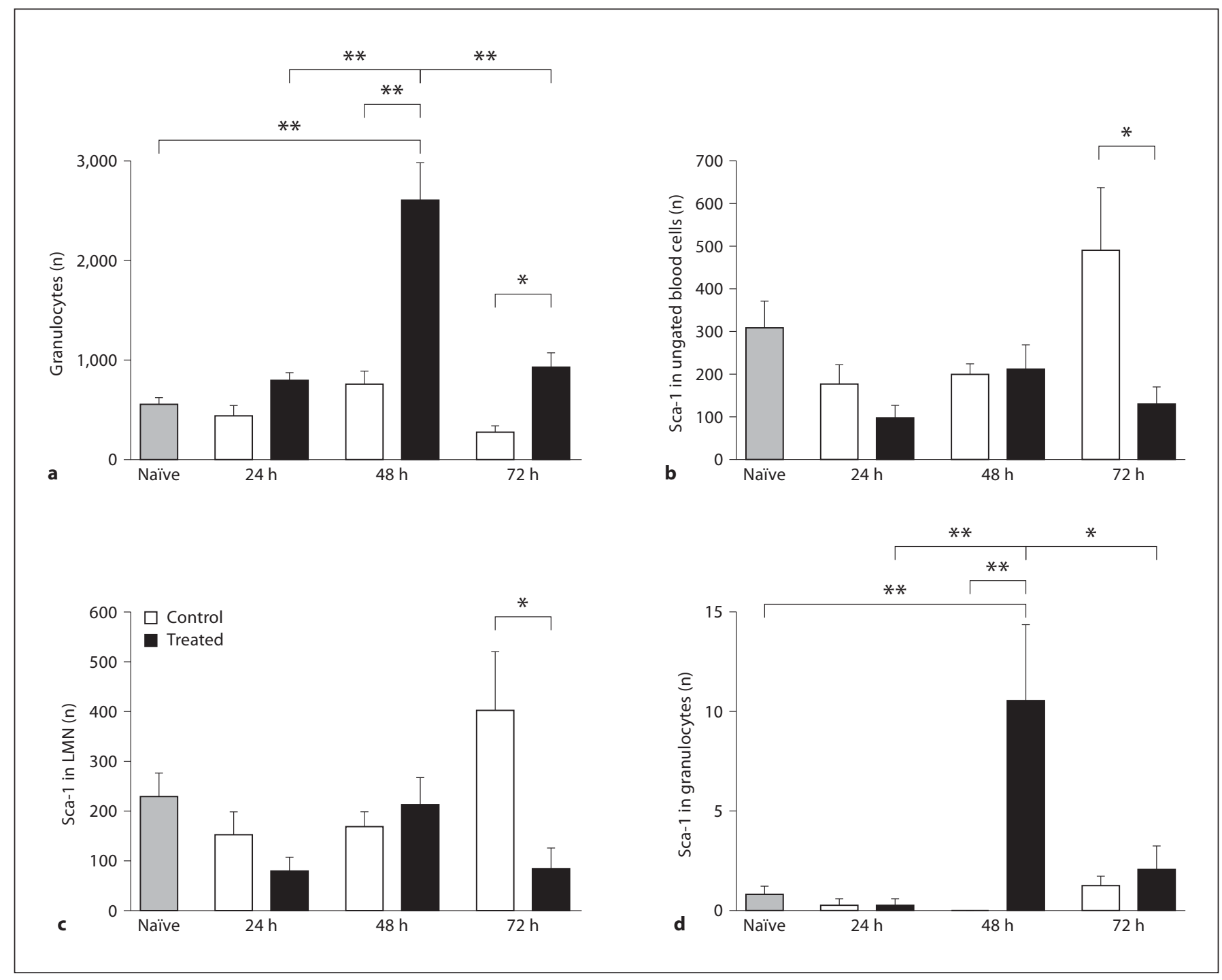

Fig. 7. Effect of LPS administration on circulating Sca- $1^{+}$cells. Numbers of granulocytes (a), Sca- $1^{+}$in ungated blood cells (b), $\mathrm{LMN}(\mathbf{c})$, and granulocytes (d) were evaluated in naïve mice and in saline- (controls) and LPS-treated mice at different time points. The number of granulocytes was obtained on the whole blood cell population stained with anti-Ly-6G/Ly-6C antibody and with high side scatter. The analysis of double positive cells for Sca-1 and lineage markers for LMN (CD19, CD3 $\varepsilon$, NK-1.1, and CD11b) and granulocytes was carried out as described in Materials and Methods. Data are shown as the mean \pm SD of 5 experiments $(n=5$ for naïve mice and $n=3-4$ for each time point and each group). ${ }^{*} \mathrm{p}<0.05 ;{ }^{* *} \mathrm{p}<0.001$. at $48 \mathrm{~h}$ in the number of Sca- $1^{+}$cells positive for CD11a and CD49d, this effect did not yield significance in comparison with untreated mice (not shown).

We sought also to determine any correlation between circulating cells and pulmonary inflammatory markers. We found that there was a positive correlation between the number of granulocytes and cytokine/chemokine levels in BALF: at $48 \mathrm{~h}$ with TNF- $\alpha$ and $\mathrm{KC}$, and at $72 \mathrm{~h}$ with KC and SDF-1 (all $r_{s}=1$ and $p<0.001$ ). A positive correlation was found also between Sca- $1^{+}$cells in the ungated population and KC BALF levels at $72 \mathrm{~h}$, and between Sca- $1^{+}$cells in the lymphomonocyte population and the total number of inflammatory cells and IL-6 BALF levels at $72 \mathrm{~h}$ (all $\mathrm{r}_{\mathrm{s}}=1$ and $\left.\mathrm{p}<0.001\right)$. A significant positive correlation was found between SDF-1 serum levels and the number of Sca-1-positive cells in the ungated and lymphomonocyte blood population at $72 \mathrm{~h}$ (both with $r_{s}=1$ and $\left.p<0.001\right)$. 


\section{Discussion}

In this report we document a temporal relationship between a pulmonary increase in inflammatory cytokines and chemokines and VLA- 4 and CXCR4 on marrow HSPCs at $48 \mathrm{~h}$ and increased chemotaxis of HSPCs in conjunction with decreased levels of circulating stem/ progenitor cells at $72 \mathrm{~h}$ in a model of acute pulmonary inflammation. So far, the role of neutrophils in this model has been investigated in terms of an acute inflammatory response (up to $24 \mathrm{~h}$ ) and not as persistent inflammation [25]. Others have studied the mobilization of EPCs in the LPS model at 1 week and found that EPCs increased in the circulation and homed to the lung giving rise to alveolar epithelial and endothelial cells [5], but the role of HSPCs was not studied. However, the significance of circulating neutrophils was substantiated in the lung inflammatory model presented in this paper by the positive correlation we found with BAL levels of KC and TNF$\alpha$ at $48 \mathrm{~h}$ and of KC and SDF-1 at $72 \mathrm{~h}$.

The interaction between VLA- $4\left(\alpha_{4} \beta_{1}\right)$ on HSPCs and VCAM-1 on stromal cells has been implicated in the retention of HSPCs in the bone marrow [26-29]. Disruption of this interaction by neutralizing antibodies directed against VLA-4 or VCAM-1 [16] or bone marrow neutrophils [30] resulted in HSPC mobilization. In the present study, the elevation of VLA-4 expression in HSPCs (fig. 4) is coincident with the cytokine/chemokine increase in BALF (fig. 3), and precedes increased HSPC chemotaxis along an SDF-1 gradient at $72 \mathrm{~h}$ (fig. 6), when VLA-4 returns to basal levels. Overall, these results suggest that cytokines/chemokines are involved in the initial increase in VLA-4 levels on marrow stem/progenitor cells and that, in coincidence with the drop of VLA-4 at $72 \mathrm{~h}$, this and other factors are involved in the mobilization of HSPCs. This hypothesis is strengthened by the finding of a positive correlation between the number of HSPCs positive for CD49d and chemokine levels in BALF, indicating that MIP-2 and KC are involved, besides neutrophil egress from the bone marrow, also in preparing HSPCs to exit from the bone marrow.

Although HSPC proliferation is associated with their mobilization from the bone marrow [15, 21, 31, 32], we did not find any change in $\mathrm{Ki} 67^{+} \mathrm{HSPCs}$ upon LPS challenge (fig. 3). Ki67 nuclear staining has been reported to agree with conventional proliferation assays (BrdU incorporation and dye dilution) in assaying lymphoproliferation [33]. Furthermore, the low percentages of $\mathrm{Ki}^{+} 7^{+} \mathrm{HSPCs}$ found in this study are in line with previous reports showing that the mouse HSPCs are largely quiescent with a small percentage in the $S / G 2 / M$ phase [34]. These observations are not unexpected since it has been previously shown that different mobilization protocols may be independent of cell cycle status [35].

In humans, the expression of $\beta_{2}$-integrin LFA-1 $\left(\alpha_{\mathrm{L}} \beta_{2}\right.$; $\mathrm{CD} 11 \mathrm{a} / \mathrm{CD} 18)$ is confined to the more mature HSPCs, and blocking LFA-1 with neutralizing antibodies completely prevented the IL-8-induced mobilization of HSPCs with colony-forming or radioprotective capacity in mice. However, the role of $\beta_{2}$-integrins in the adhesion of HSPCs to stromal cells is controversial. Teixidó et al. [28] found that anti- $\beta_{2}$ antibodies partially blocked the adhesion of $\mathrm{CD} 34^{\text {high }}$ cells to stromal cells, while antibodies directed against $\beta_{2}$-integrins were unable to mobilize progenitors into the bloodstream $[10,36]$. It has been hypothesized that abrogation of $\beta_{2}$-integrin function contributes to significant mobilization when $\alpha_{4} \beta_{1^{-}}$ integrin is concurrently inhibited [37]. Our data, showing that CD11a levels do not change during a sustained pulmonary inflammation, suggest that LFA-1 is not likely involved in HSPC mobilization in this model.

L-selectin expression is higher on the more primitive population of mobilized CD34 $4^{+}$cells [19], and the degree of hematopoietic recovery following chemotherapy correlates with the expression of L-selectin on CD $34^{+}$human HSPCs [20], although L-selectin does not appear to contribute to HSPC interactions in bone marrow microvessels [38] and in fucoidan-induced mobilization in mice [39]. To account for these differences, it should be considered that Sca-1 in mice is similar to c-kit in detecting very primitive hematopoietic stem cells (HSCs) whereas CD34 recognizes a pool of progenitor cells (including EPCs) able to repopulate the bone marrow upon transplantation in humans, although it does not necessarily identify true stem cells. Nevertheless, in the model of pulmonary inflammation used in this study, it seems that L-selectin does not play a significant role, like in CD11a, and these data indicate that a selective effect on VLA- 4 has been obtained. It has been shown that mobilized CD34 ${ }^{+}$cells show a different pattern of expression for LFA-1, VLA-4, and L-selectin [19]. Overall, these data indicate that, like for the homing process, the mobilization of HSPCs from the bone marrow is dependent on a different set of adhesion molecules belonging to either selectin or integrin families.

HSPCs can be mobilized from the bone marrow parenchyma to the circulation by various agonists whose common downstream action leads to alteration of the expression or function of the chemokine CXCL12/SDF-1 and adhesion molecules mediating migration $[8,40]$. At 
least two different mechanisms disrupt the CXCL12CXCR4 chemotactic axis during HSC egress. First, CXCL12 and CXCR4 reductions coincide with the induction of proteolytic activity in the bone marrow [41]. The second mechanism involves the desensitization of CXCR4 and consequent stem cell entry into the circulation [42]. Irrespective of the mechanism, our data indicate that CXCR4 expression fluctuates during LPS-induced pulmonary inflammation and that, after an initial increase at $48 \mathrm{~h}$, its levels decrease, although not sharply, at $72 \mathrm{~h}$. At this time point, a significant increase in HSPC chemotaxis was observed. It should be stressed that bovine and murine endothelial cell types allow adhesion of murine progenitor T cells in the same amount and with the same molecular mechanism, i.e. CD49d dependent [43]. So, bovine endothelial cells are an appropriate cell model to investigate murine HSPC chemotaxis.

On the other hand, CXCL12 is released from injured lungs to recruit CXCR4 bone marrow-derived HSPCs in murine models of pulmonary fibrosis $[44,45]$, indicating that the CXCL12/CXCR4 axis is critical in the bone marrow response to some kind of lung injury. Thus, it seems that a balance between bone marrow and peripheral CXCL12 levels is critical for HSPC mobilization from bone marrow to the injured tissues. In the model presented in this paper, serum SDF-1 levels significantly increased in LPS-treated mice at all time points compared to the control group. However, blocking SDF-1 with an intravenously administered blocking antibody did not exert any effect on CD49d expressed on whole HSPCs and R1/R2 subpopulations at $48 \mathrm{~h}$ following LPS treatment (data not shown), and these data suggest that the marrow SDF-1 gradient was not disrupted. Alternatively, other chemokines, such as KC and MIP-2 [46, 47], could be relevant for HSPC mobilization in this model (see discussion above). Indeed, the absolute number of granulocytes and the number of Sca- $1^{+}$cells in the granulocyte population were increased by the LPS treatment at $48 \mathrm{~h}$. Overall, we can only suggest that HSPCs are induced to migrate from the bone marrow into the blood circulation along chemotactic gradients upon the induction of ALI and are likely endowed with different properties depending on which blood population they belong to. Indeed, Sca- $1^{+}$cells in the ungated population correlated with KC BALF levels at $72 \mathrm{~h}$, and the number of Sca- $1^{+}$cells in the ungated and lymphomonocyte blood population correlated with SDF-1 serum levels at $72 \mathrm{~h}$. Altogether, these data indicate a relevance of KC and SDF-1 for HSPC mobilization from the marrow to the blood at later time points.
The apparent discrepancy between the increase in resident HSPC chemotaxis and the decrease in circulating HSPCs at $72 \mathrm{~h}$ may reflect different in vitro and in vivo kinetics. Alternatively, HSPCs entered into the circulation migrate faster out of the blood, and their decrease may indicate their entry into the lung. Thus, we sought to determine whether these cells could be found at the lung level by investigating a specific marker. ALDH 9 family member A1 (ALDH9A1) is expressed by HSPCs [48] and at very low levels in the lung [49]. Thus, the influx of HSPCs into the lung was studied by analyzing the levels of ALDH9A1 in lung homogenates following LPS treatment. However, we could not detect any difference between control and treated mice at any time points. These data strongly suggest that if a migration of circulating Sca-1-positive cells happened in the time frame of the experiments presented in this paper, the level of engraftment was much too low to be detected by this assay. These results are in line with those presented by our and other groups demonstrating that the level of engraftment is not higher than $0.01-0.025 \%$ of the total lung cells [reviewed in 50].

Many studies point to intrinsic heterogeneity in HSCs [51-54], and even in functionally identified stem cell populations, cellular and molecular properties and behavior can be diverse $[54,55]$. We have previously shown that resident HSPCs are comprised of two subsets as determined by physical parameters and mitochondrial content [23]. R1 (bigger) cells are less primitive in that they display higher levels of mitochondria, as also shown in human $\mathrm{CD} 4^{+}$cells [56]. The R1 subset of resident HSPCs showed the higher expression of CD $49 \mathrm{~d}$ at $48 \mathrm{~h}$ in LPSinjected mice compared to controls (fig. 5), similarly to the whole population, suggesting that R1 cells should preferentially migrate from the bone marrow. Indeed, the R1 subpopulation was found to transmigrate through the endothelium, a finding which is in agreement with the report of Mohle et al. [57] who found that transmigrated CD $34^{+}$cells expressed higher levels of CD38 compared with nonmigrating cells and may therefore represent predominantly committed progenitor cells. Interestingly, the number of $\mathrm{R} 1$ cells positive for CD49d correlated with SDF-1 and KC at 48 and $72 \mathrm{~h}$, respectively, indicating a role for both of these chemokines in the mobilization of this subset of HSPCs; however, this hypothesis should be confirmed by further work.

In summary, our data are suggestive of a temporal relationship among elevation of inflammatory cytokines/ chemokines in the lung, modification of CD49d and CXCR4 expression in resident marrow HSPCs, chemotax- 
is of HSPCs, and a decrease in circulating Sca- $1^{+}$cells in the blood. We can only speculate that the HSPC subset with the bigger size is involved in the mobilization process. Their precise role in the early and late phases of the inflammatory process in the lung remains to be analyzed.

\section{Acknowledgements}

This work was supported by a grant from Fondazione Banca del Monte Domenico Siniscalco-Ceci. We thank Angela Sansone for supporting us with supplies.

\section{References}

$\checkmark 1$ Ware LB, Matthay MA: The acute respiratory distress syndrome. N Engl J Med 2000; 342:1334-1349.

-2 Matute-Bello G, Frevert CW, Martin TR: Animal models of acute lung injury. Am J Physiol Lung Cell Mol Physiol 2008;295: L379-L399.

3 Chen H, Bai C, Wang X: The value of the lipopolysaccharide-induced acute lung injury model in respiratory medicine. Expert Rev Respir Med 2010;4:773-783.

4 Kubo H, Graham L, Doyle NA, Quinlan WM, Hogg JC, Doerschuk CM: Complement fragment-induced release of neutrophils from bone marrow and sequestration within pulmonary capillaries in rabbits. Blood 1998;92:283-290.

-5 Yamada M, Kubo H, Kobayashi S, Ishizawa K, Numasaki M, Ueda S, Suzuki T, Sasaki H: Bone marrow-derived progenitor cells are important for lung repair after lipopolysaccharide-induced lung injury. J Immunol 2004;172:1266-1272.

-6 Yamada M, Kubo H, Ishizawa K, Kobayashi S, Shinkawa M, Sasaki H: Increased circulating endothelial progenitor cells in patients with bacterial pneumonia: evidence that bone marrow derived cells contribute to lung repair. Thorax 2005;60:410-413.

$\checkmark 7$ Hollingsworth JW, Chen BJ, Brass DM, Berman K, Gunn MD, Cook DN, Schwartz DA: The critical role of hematopoietic cells in lipopolysaccharide-induced airway inflammation. Am J Respir Crit Care Med 2005; 171: 806-813.

8 Mendez-Ferrer S, Frenette PS: Hematopoietic stem cell trafficking: regulated adhesion and attraction to bone marrow microenvironment. Ann NY Acad Sci 2007;1116:392413.

-9 Mazo IB, Massberg S, von Andrian UH: Hematopoietic stem and progenitor cell trafficking. Trends Immunol 2011;32:493-503.

10 Papayannopoulou T, Nakamoto B: Peripheralization of hemopoietic progenitors in primates treated with anti-VLA4 integrin. Proc Natl Acad Sci USA 1993;90:9374-9378.

-11 Abraham M, Biyder K, Begin M, Wald H, Weiss ID, Galun E, Nagler A, Peled A: Enhanced unique pattern of hematopoietic cell mobilization induced by the CXCR4 antagonist 4F-benzoyl-TN14003. Stem Cells 2007; 25:2158-2166.
12 Scott LM, Priestley GV, Papayannopoulou T: Deletion of alpha4 integrins from adult hematopoietic cells reveals roles in homeostasis, regeneration, and homing. Mol Cell Biol 2003;23:9349-9360.

13 Priestley GV, Ulyanova T, Papayannopoulou T: Sustained alterations in biodistribution of stem/progenitor cells in Tie2Cre+alpha4(f/f) mice are hematopoietic cell autonomous. Blood 2007;109:109-111.

14 Foudi A, Jarrier P, Zhang Y, Wittner M, Geay JF, Lecluse Y, Nagasawa T, Vainchenker W, Louache F: Reduced retention of radioprotective hematopoietic cells within the bone marrow microenvironment in CXCR4-/chimeric mice. Blood 2006;107:2243-2251.

15 Papayannopoulou T, Scadden DT: Stem-cell ecology and stem cells in motion. Blood 2008;111:3923-3930.

16 Papayannopoulou T, Craddock C, Nakamoto B, Priestley GV, Wolf NS: The VLA4/ VCAM-1 adhesion pathway defines contrasting mechanisms of lodgement of transplanted murine hemopoietic progenitors between bone marrow and spleen. Proc Natl Acad Sci USA 1995;92:9647-9651.

17 Hidalgo A, Peired AJ, Weiss LA, Katayama Y, Frenette PS: The integrin alphaMbeta2 anchors hematopoietic progenitors in the bone marrow during enforced mobilization. Blood 2004;104:993-1001.

18 Papayannopoulou T, Priestley GV, Nakamoto B, Zafiropoulos V, Scott LM: Molecular pathways in bone marrow homing: dominant role of alpha(4)beta(1) over beta(2)-integrins and selectins. Blood 2001;98:2403-2411.

19 Mohle R, Murea S, Kirsch M, Haas R: Differential expression of L-selectin, VLA-4, and LFA-1 on CD34+ progenitor cells from bone marrow and peripheral blood during G-CSF-enhanced recovery. Exp Hematol 1995;23:1535-1542.

20 Dercksen MW, Gerritsen WR, Rodenhuis S, Dirkson MK, Slaper-Cortenbach IC, Schaasberg WP, Pinedo HM, von dem Borne AE, van der Schoot CE: Expression of adhesion molecules on CD34+ cells: CD34+ L-selectin + cells predict a rapid platelet recovery after peripheral blood stem cell transplantation. Blood 1995;85:3313-3319.

21 Nervi B, Link DC, DiPersio JF: Cytokines and hematopoietic stem cell mobilization. J Cell Biochem 2006;99:690-705.
22 Becker PS, Nilsson SK, Li Z, Berrios VM, Dooner MS, Cooper CL, Hsieh CC, Quesenberry PJ: Adhesion receptor expression by hematopoietic cell lines and murine progenitors: modulation by cytokines and cell cycle status. Exp Hematol 1999;27:533-541.

23 Piro D, Piccoli C, Guerra L, Sassone F, D’Aprile A, Favia M, Castellani S, Di Gioia S, Lepore S, Garavaglia ML, Trotta T, Maffione $A B$, Casavola V, Meyer G, Capitanio N, Conese M: Hematopoietic stem/progenitor cells express functional mitochondrial energy-dependent cystic fibrosis transmembrane conductance regulator. Stem Cells Dev 2012; 21:634-646.

24 Paganessi LA, Walker AL, Tan LL, Holmes I, Rich E, Fung HC, Christopherson KW 2nd: Effective mobilization of hematopoietic progenitor cells in G-CSF mobilization defective CD26-/- mice through AMD3100-induced disruption of the CXCL12-CXCR4 axis. Exp Hematol 2011;39:384-390.

25 Petty JM, Sueblinvong V, Lenox CC, Jones CC, Cosgrove GP, Cool CD, Rai PR, Brown KK, Weiss DJ, Poynter ME, Suratt BT: Pulmonary stromal-derived factor-1 expression and effect on neutrophil recruitment during acute lung injury. J Immunol 2007;178:8148-8157.

26 Simmons PJ, Masinovsky B, Longenecker BM, Berenson R, Torok-Storb B, Gallatin WM: Vascular cell adhesion molecule-1 expressed by bone marrow stromal cells mediates the binding of hematopoietic progenitor cells. Blood 1992;80:388-395.

27 Williams DA, Rios M, Stephens C, Patel VP: Fibronectin and VLA-4 in haematopoietic stem cell-microenvironment interactions. Nature 1991;352:438-441.

28 Teixidó J, Hemler ME, Greenberger JS, Anklesaria P: Role of beta 1 and beta 2 integrins in the adhesion of human CD34hi stem cells to bone marrow stroma. J Clin Invest 1992; 90:358-367.

29 Oostendorp RA, Dormer P: VLA-4-mediated interactions between normal human hematopoietic progenitors and stromal cells. Leuk Lymphoma 1997;24:423-435.

30 Levesque JP, Takamatsu Y, Nilsson SK, Haylock DN, Simmons PJ: Vascular cell adhesion molecule-1 (CD106) is cleaved by neutrophil proteases in the bone marrow following hematopoietic progenitor cell mobilization by granulocyte colony-stimulating factor. Blood 2001;98:1289-1297. 
$>31$ Cancelas JA, Jansen M, Williams DA: The role of chemokine activation of Rac GTPases in hematopoietic stem cell marrow homing, retention, and peripheral mobilization. Exp Hematol 2006;34:976-985.

32 Mohle R, Kanz L: Hematopoietic growth factors for hematopoietic stem cell mobilization and expansion. Semin Hematol 2007;44: 193-202.

33 Soares A, Govender L, Hughes J, Mavakla W, de Kock M, Barnard C, Pienaar B, Janse van Rensburg E, Jacobs G, Khomba G, Stone L, Abel B, Scriba TJ, Hanekom WA: Novel application of Ki67 to quantify antigen-specific in vitro lymphoproliferation. J Immunol Methods 2010;362:43-50.

-34 Davis TA, Mungunsukh O, Zins S, Day RM, Landauer MR: Genistein induces radioprotection by hematopoietic stem cell quiescence. Int J Radiat Biol 2008;84:713-726.

35 To LB, Haylock DN, Dowse T, Simmons PJ, Trimboli S, Ashman LK, Juttner CA: A comparative study of the phenotype and proliferative capacity of peripheral blood (PB) CD34+ cells mobilized by four different protocols and those of steady-phase $\mathrm{PB}$ and bone marrow CD34+ cells. Blood 1994;84:29302939.

-36 Bradstock K, Makrynikola V, Bianchi A, Byth K: Analysis of the mechanism of adhesion of precursor-B acute lymphoblastic leukemia cells to bone marrow fibroblasts. Blood 1993;82:3437-3444.

-37 Papayannopoulou T, Priestley GV, Nakamoto B, Zafiropoulos V, Scott LM, Harlan JM: Synergistic mobilization of hemopoietic progenitor cells using concurrent betal and beta2 integrin blockade or beta2-deficient mice. Blood 2001;97:1282-1288.

38 Mazo IB, Gutierrez-Ramos JC, Frenette PS, Hynes RO, Wagner DD, von Andrian UH: Hematopoietic progenitor cell rolling in bone marrow microvessels: parallel contributions by endothelial selectins and vascular cell adhesion molecule 1. J Exp Med 1998; 188:465-474.
39 Frenette PS, Weiss L: Sulfated glycans induce rapid hematopoietic progenitor cell mobilization: evidence for selectin-dependent and independent mechanisms. Blood 2000;96: 2460-2468.

40 Chan JY, Watt SM: Adhesion receptors on haematopoietic progenitor cells. Br J Haematol 2001;112:541-557.

41 Levesque JP, Hendy J, Takamatsu Y, Simmons PJ, Bendall LJ: Disruption of the CXCR4/CXCL12 chemotactic interaction during hematopoietic stem cell mobilization induced by GCSF or cyclophosphamide. J Clin Invest 2003;111:187-196.

42 Shen H, Cheng T, Olszak I, Garcia-Zepeda E, Lu Z, Herrmann S, Fallon R, Luster AD, Scadden DT: CXCR-4 desensitization is associated with tissue localization of hemopoietic progenitor cells. J Immunol 2001;166: 5027-5033.

43 Aparicio CL, Berthiaume F, Chang CC, Yarmush ML: Tumor necrosis factor-alpha (TNF-alpha) induces a reversible, time- and dose-dependent adhesion of progenitor $\mathrm{T}$ cells to endothelial cells. Mol Immunol 1996; 33:671-680.

44 Xu J, Mora A, Shim H, Stecenko A, Brigham KL, Rojas M: Role of the SDF-1/CXCR4 axis in the pathogenesis of lung injury and fibrosis. Am J Respir Cell Mol Biol 2007;37:291299.

45 Song JS, Kang CM, Kang HH, Yoon HK, Kim YK, Kim KH, Moon HS, Park SH: Inhibitory effect of CXC chemokine receptor 4 antagonist AMD3100 on bleomycin induced murine pulmonary fibrosis. Exp Mol Med 2010; 42:465-472.

46 van Pel M, van Os R, Velders GA, Hagoort H, Heegaard PM, Lindley IJ, Willemze R, Fibbe WE: Serpinal is a potent inhibitor of IL-8induced hematopoietic stem cell mobilization. Proc Natl Acad Sci USA 2006;103:14691474.

47 Wang J, Mukaida N, Zhang Y, Ito T, Nakao S, Matsushima K: Enhanced mobilization of hematopoietic progenitor cells by mouse MIP-2 and granulocyte colony-stimulating factor in mice. J Leukoc Biol 1997;62:503509.
48 Levi BP, Yilmaz OH, Duester G, Morrison SJ: Aldehyde dehydrogenase la1 is dispensable for stem cell function in the mouse hematopoietic and nervous systems. Blood 2009; 113:1670-1680.

49 Alnouti Y, Klaassen CD: Tissue distribution, ontogeny, and regulation of aldehyde dehydrogenase (Aldh) enzymes mRNA by prototypical microsomal enzyme inducers in mice. Toxicol Sci 2008;101:51-64.

50 Kassmer SH, Krause DS: Detection of bone marrow-derived lung epithelial cells. Exp Hematol 2010;38:564-573.

-51 Cross MA, Heyworth CM, Murrell AM, Bockamp EO, Dexter TM, Green AR: Expression of lineage restricted transcription factors precedes lineage specific differentiation in a multipotent haemopoietic progenitor cell line. Oncogene 1994;9:3013-3016.

52 Chang $\mathrm{HH}$, Hemberg M, Barahona M, Ingber DE, Huang S: Transcriptome-wide noise controls lineage choice in mammalian progenitor cells. Nature 2008;453:544-547.

53 Graf T, Enver T: Forcing cells to change lineages. Nature 2009;462:587-594.

54 Dykstra B, Kent D, Bowie M, McCaffrey L, Hamilton M, Lyons K, Lee SJ, Brinkman R, Eaves C: Long-term propagation of distinct hematopoietic differentiation programs in vivo. Cell Stem Cell 2007;1:218-229.

55 Lemischka IR, Raulet DH, Mulligan RC: Developmental potential and dynamic behavior of hematopoietic stem cells. Cell 1986;45: 917-927.

56 Piccoli C, Ria R, Scrima R, Cela O, D’Aprile A, Boffoli D, Falzetti F, Tabilio A, Capitanio $\mathrm{N}$ : Characterization of mitochondrial and extra-mitochondrial oxygen consuming reactions in human hematopoietic stem cells: novel evidence of the occurrence of NAD $(\mathrm{P})$ $\mathrm{H}$ oxidase activity. J Biol Chem 2005;280: 26467-26476.

57 Mohle R, Moore MA, Nachman RL, Rafii S: Transendothelial migration of CD34+ and mature hematopoietic cells: an in vitro study using a human bone marrow endothelial cell line. Blood 1997;89:72-80. 